\title{
Effects of Banks' Loan Collateral Requirement on Performance of Small and Medium Enterprises in Maua Town, Meru County, Kenya
}

\author{
Johnson Mwirigi Rithaa, Haldess Nguta Munene, Dr. Ann Kariuki
}

\begin{abstract}
In the contemporary business arena, few businesses operate without credit from banks, with small and medium enterprises (SMEs) lending portfolio by banks in Kenya estimated at KSh332 billion. However,Four hundred thousand SMEs did not see their second anniversary in the recent past in Kenya raising questions about the impact of banks loan collateral requirement on success of the SMEs. The purpose of this study was to establish the effect of banks credit accessibility on the performance of small and medium enterprises in Maua Town, Meru County, Kenya. Maua is a cosmopolitan urban centre serving the entire Igembe region of Meru County as well as parts of Isiolo County. Specifically, the study sought to evaluate the effect of loan collateral requirements on the performance of SMEs in Maua Town. The population of the study comprised 250 registered SMEs licensed in Maua Town by the County Government of Meru. Using stratified and simple random, 153 enterprises were selected as the sample of the study. Data was collected using questionnaires and analysed using SPSS Version 21 and presented using frequency tables. Regression Analysis was used to establish the effect of the independent variable on the dependent variable. Linear regression analysis indicated that the independent variable (collateral requirements) had a negative effect on performance of SMEs. The study recommended that banks should review collateral demands for SME owners to allow for more items of value to be used as security as this will encourage businesspeople to borrow.
\end{abstract}

Index Terms - Access to Finance, Financial Performance, SME,Profitability.

\section{INTRODUCTION}

Small and Medium Enterprises refer to business enterprises that have a specific range of turnover, employees as well as asset levels. Different countries have different definitions of SMEs. Under the Micro, Small Enterprises Act of 2012, Small enterprises have annual turnovers of between Ksh 500,000 and 5 million and employ 10-49 people (Micro \& Small Enterprises Act, 2012). Medium enterprises are not covered under the act, but have been reported as comprising of enterprises with a turnover of between Ksh 5 million and 100 million and employees between 50 and 250.

Small and medium enterprises are recognized throughout

Johnson Mwirigi Rithaa, Masters of Business Administration Student, Meru university of Science and Technology, Kenya

HaldessNguta Munene, Lecturer,Meru university of Science and Technology, Kenya Kenya the world for playing an important role in the growth of the countries' economies and creating employment. They constitute over $99 \%$ of all the firms in the world (Capital market authority, 2015). Though small and medium enterprises play an important role to the economies of different countries such as ability to create employment, contribution to gross domestic product, alleviation of poverty as well as distribution of income, they face enormous challenges. Indeed, lack of adequate affordable finances is a major challenge for small and medium enterprises. However, lending institutions have stood out as major financiers to small and medium enterprises. These lending institutions, nonetheless, use certain criteria, guided by the institutions credit policy, in granting loans to these SME's. Whereas borrowers seek to benefit from the granted credit, the lenders focus on reducing the credit risk. Thus, lenders vary the credit policy from time to time based on their perceived risk which in turn affect credit accessibility. This variation in credit policy affects the borrowers' business in certain ways, giving impetus to this study on the effect of banks credit accessibility on the performance of the SME's

Within the European Union, 99\% (23 million) of all companies are SME's. They are the foundation for innovation, competition and jobs (European Central Bank, 2016). These SME's provide two thirds of private sector jobs. Nonetheless, small and medium enterprises face many challenges globally. A survey by European Central Bank shows that $9 \%$ of the SME's felt that they had challenges with accessing finance (European Central Bank, 2016).The European commission has drafted a common joint European Union policy on SME's which helps to monitor the progress in implementing and sharing best practices on SME's amongst the EU countries A survey on "access to finance" European Central Bank(ECB, 2013) showed that smaller firms have more problems accessing finances compared to larger firms in Europe. They identify stringent credit policy from lenders, for smaller firms who face challenges raising the required collaterals thus ending up not accessing the requested credit.

Indeed $54 \%$ of SME's use only external financing compared to $43 \%$ of large firms (ECB, 2013). Further, the safe survey found that the collateral requirement are higher for SME firms compared to larger firms. This minimizes the profit margin of the respective SME and makes them less competitive compared to large corporates. However, SME's still prefer to use bank loans to finance their businesses. Due 
to this, the EU has launched several initiatives to address the specific financing problems of SME's. The use of EU structural and cohesion funds, financial support by European investment bank; and the European investment funds specifically for SME's through provision of loans and trade finance facilities helps SME's to grow (Ciani, Russo and Vacca,2015). This has helped in improving performance of SME firms in Europe.

In Africa, SME's constitute about $99 \%$ of all the firms and contribute between 50 to $60 \%$ of all the employment (United Nations Industrial Development Organisation (2012). Access to finances in Africa, unlike in Europe, ranks as the top issue affecting the performance of SMEs (Deiana and Minsat, 2017). Almost $20 \%$ of formal companies cites access to finance as a constraint to their business success (Deiana and Minsat, 2017). In Africa Small enterprises are 30\% less likely to access bank loans compared to medium enterprises (Deiana and Minsat, 2017). This is mainly due to stringent requirement by the lending institutions which demands for conventional securities among other requirements before granting the loan requested. Regrettably, 91\% of SME's consider access to credit as a major constraint to their performance in Africa compared to $49 \%$ in South Asia (World Bank, 2010). Therefore, credit accessibility has a significant impact on the growth of small and medium enterprises (Ayuba and Zubairu, 2015).

Small and medium enterprises in Kenya have over the years been recognized for their role in creation of employment, fostering innovation, and in effect alleviation of poverty. The SME sector has been identified and prioritized as a key growth driver for achievement of development according to Kenya vision 2030 blue print; (Republic of Kenya Vision 2030, Deloitte Kenya economic outlook, 2016). However, 2.2 million SME's were closed in the recent past mainly due to constraints including lack of capital, expensive loans, poor infrastructure, stiff local competition and regulatory environment characterized by requirement of multiple licenses for the same business (KNBS, 2016).

Kenyan government has attempted to address problems being faced by SME institutions through enforcing legislation such as increasing contributions to funds such as the Uwezo Fund, Youth Enterprise Development Fund and Women Enterprise Fund (Deloitte Kenya Economic Outlook, 2016). Kenya's financial deepening (FSD) programme seeks to expand access to affordable financial services among SMEs. In 2015, FSD, central bank of Kenya and World Bank jointly conducted a research project to understand the supply and demand side of the SME market and concluded that for sustained development, SME lending must increase and improve further. In 2016, another project carried out by FSD to build capacity within Kenya's financial services sector to SMEs, showed lenders were not serving SME's effectively. Following the release of financial results for banks for the year 2016, most banks in Kenya have increased non-performing loan allocations in their balance sheet as well as reduced the profitability (CBK,2016). The major causes of this is non- payment of loans by SME's since they are the biggest borrowers in Kenyan banks (CBK, 2017).
Kenyan parliament enacted the Banking amendment act 2016, (CBK, Kenyan Gazette Supplement Acts, 2016) with a view of reducing the cost of credit to borrowers and increasing borrowing. The interest rates went down drasticallyto not more than four percent the base rate published by central bank of Kenya (Central Bank of Kenya (2016) Amendment section 33A Cap.448) after September, 2016. This amendment also provides equal product pricing irrespective of the risks attached to individual products since no bank is allowed to price its loans above the stipulated rate. Most banks have revised credit policy by varying the collateral requirement since they are not able to vary cost of credit.

Maua town has six major banks who serve Micro, Small and Medium Enterprises (KNBS, Meru County Statistical Abstract, 2015). There are also a number of microfinance institutions and Sacco's which also encroach on the same clientele. Most of the SMEs rely on the financial institutions from this area to finance their businesses. The SME's have the potential to significantly contribute to the economic growth and poverty reduction through increased production and employment opportunities (Katua, 2014). The SMEs have a multiplier effect to the economy and efforts to ensure their success can help the country improve on the living standards of its citizens. Credit policy of these banks may have either negative or positive effect on the performance of the SME's in the area. Due to increased challenge of the quality of most of the lenders loan book, banks have been revising their credit policy and this affects the SME's directly. The study was, therefore, focused on reviewing the effect of the credit accessibility which is mainly guided by the lenders credit policy on the performance of the SME's in Maua town

\section{A. Statement of the Problem}

Small and Medium Enterprises require enough working capital for operation. Banking institutions are a major source of financing to these SMEs. In financing, banks rely on existing credit policy which has set terms and conditions to be adhered to by borrowers. This affects credit accessibility and performance of the SMEs. Where credit policy is strict, SMEs may be restricted on their borrowing desire since they consider effects of the policy on their business growth, whether positive or negative.

In MeruCounty,about 18 banks are in operation with a wide 32 branch network. Seven of the banks have operational branches in Maua town. Irrespective of these number of banks in the county, the loan to deposit ratio is less than $50 \%$ amongst all the major banks (Meru county report, 2014). Guantai and Mahesh (2018) in their study on the impact assessment of micro finance to financial inclusion and business growth of the MSMEs in Igembe south, found that $21.89 \%$ have no access to financing. $27.45 \%$ of the respondent in Maua town believe that inadequate collateral is the cause of the inability to access credit (Guantai and Mahesh, 2018). In the study $57.08 \%$ of the respondents cited collateral as the major consideration by financial institutions 


\section{World Journal of Innovative Research (WJIR) ISSN: 2454-8236, Volume-6, Issue-1, January 2019 Pages 90-95}

(Guantai and Mahesh, 2018).

Further, only $23.4 \%$ of banks total loan portfolio is managed by SMEs in a country where $99 \%$ of the firms are SMEs(Guantai and Mahesh, 2018).This accounts to about 332 billion (Central Bank of Kenya (2013). Those who fail to access credit from these formal financial institutions turn to informal borrowing exposing them to unregulated, expensive and risky borrowing (Abdi, 2015). World Bank (2010) acknowledged that SMEs are more likely not to be given new loans for business purposes than larger firms when in need.

Though SMEs require financing from banks, majority of them don't survive beyold three years of operation (KNBS, 2016). This raises the question of whether the SMEs get the required financing. This study, therefore, focused on establishing how banks credit was accessible to SMEs as well as its effect on the performance of SMEs in Maua town.

\section{B. Specific Objective}

The specific objective was to evaluate the effect of loan collateral requirements on the performance of Small and Medium Enterprises

\section{Significance of the Study}

The study findings are helpful to Banks management in formulating of a quality credit policy that will help in growth of quality credits without having negative effects on SME organizations access to credit.

The study also helps SME business people to understand what the lenders are interested in and thus assist them meet the requirement of lenders on time leading to reduced time between borrowing and the time funds are availed.

The study may be useful to the government in policy making on matters relating to addressing challenges facing small and medium enterprises.

The study will be of significance to other researchers who may compare and contrast the findings of this study with others with an aim of making a conclusion, as well as for further study areas.

\section{LITERATURE REVIEW}

\section{A. Theoretical Review}

\section{Information Asymmetry Theory}

This theory was first introduced by Akerlofs in 1970 in his paper entitled "The markets for Lemons: Quality Uncertainty and the Market Mechanism" (Akerlof,1970). Information imperfection occurs when one party to a transaction has more and timely information than the other party. The theory is based on the fact that formal institutions are not able to compete successfully with informal lenders because such formal financial institutions lack better information about the borrowers than the informal lenders.

This theory suggests that it's difficult for lenders and financial analysts to make accurate decision due to the information asymmetry between the borrowers and the lenders. This theory assumes that lenders can't effectively differentiate between high risk and low risk loan applicants. Due to asymmetry information involved between the borrowers and lenders, each of the party involved needs to mitigate the risk of the decision made while transacting with each other. The lenders may request for adequate collateral as a way of mitigating the risk involved. In case of default due to such asymmetry information, they dispose the collateral attached to recover their investments. This is the reason for high importance of collateral requirement for SMEs. High credit risk which causes minimal access to banks credit is compensated by the information conveyance of collateral which significantly improves access to finance for SMEs. This theory helps to explain why lenders requests for collateral thus expounding on the objective of the effect of collateral on the performance of SMEs.

\section{B. Empirical Review}

\section{Collateral Effect on SME Performance}

Nguyen,T.,Gan,C. and Hu,M. (2015) explored the use of soft and hard information for bank lending decisions to small and medium enterprises (SMEs) in Vietnam. The study aimed at investigating to what extent different types of information were used for loan approval. The study found that although collateral based lending was the most widespread method and could substitute for other lending technologies, usually a combination of lending information types were utilized in the decision making process. This suggests that both complementary and substitutes were found in the use of the various information types by Vietnamese banks for such decision-making.

Ackah and Vuvor (2011) studied on the Challenges faced by SMEs in obtaining Credit in Ghana and found that inability to provide adequate collateral for loans to banks by borrowers as required by banks, led to inability of banks to provide loans to SME borrowers which limited the growth of the SMEs businesses. Out of the 68 respondents sampled, $60 \%$ of them attributed their lack of access to bank loans or credit to their inability to provide the required security and in situations where they are able to provide, it ends up to be inadequate, which accentuate the opinion of Binks, Ennew and Reed (1992). For them, they attributed this factor to the inability of the SMEs to provide collateral and in some cases where they do, they are inadequate and also the SMEs asset-backed collateral are usually rated at "carcass value" thereby making it difficult for these SMEs to get access to the credit they want.

Karanja, Mwangi, \&Nyakarimi (2014) investigated factors that influenced access to credit among women entrepreneurs in Isiolo town. They conducted a census on the 6 registered financial institutions, 18 management employees and 20 women entrepreneurs where descriptive survey design was adopted. They found that there was a significant relationship between the collateral requirement and access to credit services. It was also revealed that out of the firms studied, $80 \%$ asked for conventional security and this limited growth of many SMEs since they could not access enough loans for business growth. This corresponds with Muratha (2015) who studied on factors affecting credit accessibility among young entrepreneurs in Kenya and found that $63.34 \%$ of the respondents felt that collateral charged influenced the respondents accessibility of credit to a great extent. 


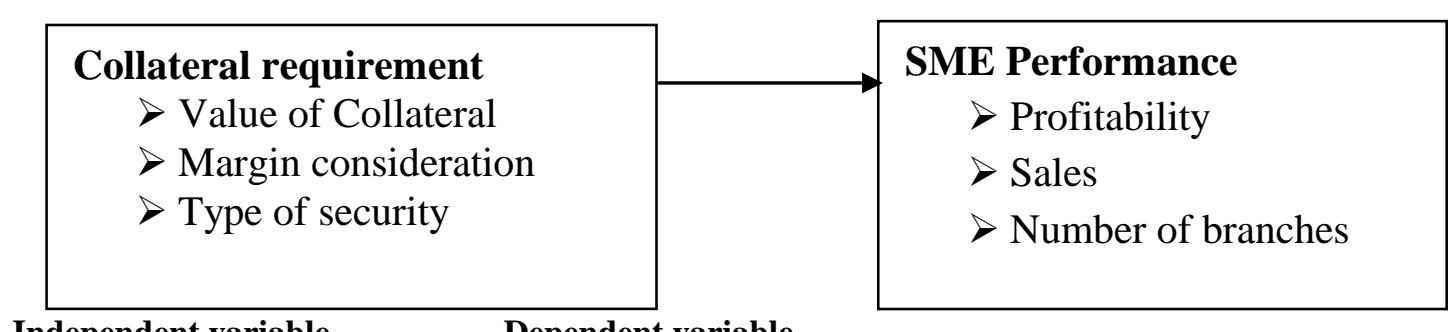

Independent variable Dependent variable Figure 1 Conceptual Framework

\section{RESEARCH METHODOLOGY}

\section{Research Design}

The study adopted descriptive research design. Descriptive survey is suitable when seeking data on certain population opinions, perceptions habits and attitudes (Orodho, 2003). This was useful in describing how collateral affects the performance of the Small and Medium Enterprises (SMEs).

\section{Scope of the Study}

This study was carried out in Maua Town, Meru County Kenya to establish effects of banks' credit accessibility on the performance of small and medium enterprises. Maua Town is a busy cosmopolitan commercial centre, whose mainstay is farming and sale of miraa / khat. Further, the study restricted itself to SME performance in the previous three years before the study.

\section{Target Population}

The study focused on 250 owners of small and medium enterprises that are registered and licensed by the County government of Meru to operate the businesses in Maua town.

\section{Sampling Procedures and Sample size}

The sample size was 153 respondent spread depending on the strength of the specific strata. This sample size was calculated using Yamane (1967) formula $\mathrm{n}=\mathrm{N} / 1+\mathrm{N}(\mathrm{e})^{\wedge} 2$ where $\mathrm{n}$ is the sample size $\mathrm{N}$ is the population (250) and e is the degree of precision at $5 \%$ and $95 \%$ confidence level. The samples per strata was as follows;

$$
\mathrm{N}=250 /\left(1+250(0.05)^{\wedge} 2\right)=153
$$

Table 1 Sample Size

\begin{tabular}{llll}
\hline Category & Population & Percentage & Sample \\
\hline Education, Health \& Entertainment & 47 & 19 & 29 \\
Hospitality \& Finance & 39 & 16 & 24 \\
General Traders & 133 & 53 & 81 \\
Manufacturing, clothing and textiles & 31 & 12 & 19 \\
\hline Total & $\mathbf{2 5 0}$ & $\mathbf{1 0 0}$ & $\mathbf{1 5 3}$ \\
\hline
\end{tabular}

\section{Research Instruments}

Questionnaires were used to collect data. This instrument collected both quantitative and qualitative data using closed and open-ended sections respectively.

\section{Methods of Data Analysis}

The researcher checked the interview schedules for completeness, errors, correctness and relevance of responses and entered the raw data into SPSS Version 21 after collection of the data. The results were presented using frequency tables. The data collected was analyzed using both descriptive and inferential statistics. Descriptive

\section{FINDINGS AND DISCUSSIONS}

From the findings of the study, majority $(70.3 \%)$ of the respondents approved that demand for collateral before accessing a loan had a negative effect on loan approval success rate. This finding is consistent with previous studies by AckahandVuvor(2011) who found that inability to provide the requested collateral to banks by borrowers led to inability of banks to provide loans to SME borrowers leading to limited growth of their businesses. Further, $62.8 \%$ asserted that banks are not flexible on the type and value of security requested to secure a loan. This was mostly after the capping of interest rates law in the year 2016(CBK,2016)with $75.9 \%$ indicating that banks increased collateral requirement after implementation of the interest rate capping law. This agrees with Central Bank of Kenya (2018) study on impact of interest rate capping law to the economy that indicated that banks had tightened collateral standards before lending.

Though it's understandable that banks need to cushion themselves against risks of default, $66.9 \%$ are of the feeling that the lenders are not fair on collateral demand, with $29 \%$ advocating for alternative securities such as chattels that are more accessible since most SMEs lack conventional security.

On the effect of demand for collateral on business performance, $75.9 \%$ postulate that businesses are affected negatively. This may be due to the fact that SMEs may be denied access to credit due to lack of collateral, hence lacking funds for expansion and growth. This supports the findings by Etemesi (2017) who found that increase in collateral requirement would lead to a decrease in growth of SMEs by a factor of -0.417 . 
World Journal of Innovative Research (WJIR)

ISSN: 2454-8236, Volume-6, Issue-1, January 2019 Pages 90-95

Table 2: Relationship Between Collateral Requirements and Performance of SMEs

\title{
Coefficients
}

Model

\author{
Unstandardized \\ Coefficients
}

Standardized

$\mathrm{t}$

Coefficients

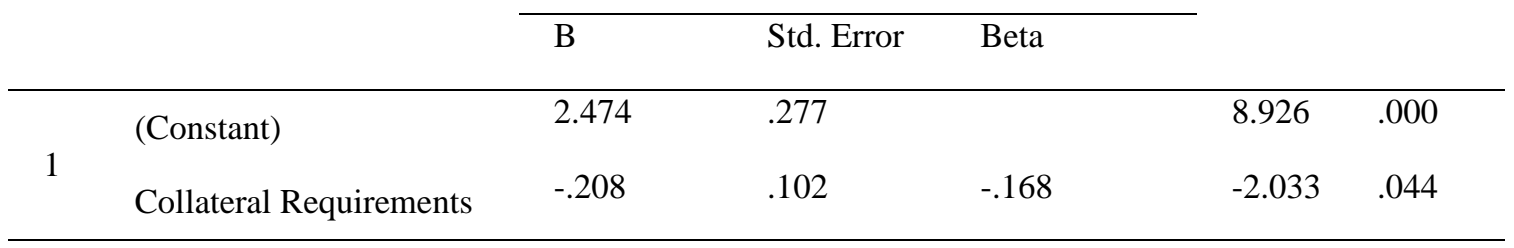

a.Dependent Variable: Performance of SMEs

The linear regression analysis shows for the independent variable there is negative coefficient which implies a negative relationship between the dependent and the independent variable. This implies that for every increase in collateral requirement by one unit, SMEs performance reduces by a margin of -0.208 . The relationship is statistically significantly tested on the p-value which is less than $5 \%$.

\section{CONCLUSIONS}

The study established that collateral requirements had a negative effect on SMEs' performance. Business people in

Maua Town relied on credit from banks considering they borrow within the first years of business operation. Collateral demands impacted such aspects as loan approval success rate. Further, banks were not flexible on collateral matters especially in terms of the type and value of the security. Such challenges are likely to impact borrowing by marginalised entrepreneurs like women and youth who may not have access to conventional collateral such as motor vehicle log books and land title deeds. It is significant, also that the Interest Rates Capping Law resulted in banks increasing collateral demands with banks keen on shielding themselves from potential loan defaulters, thus curtailing the borrowing abilities of SMEs. Collateral margins for determining loan amounts were also not fair to SME owners. It is evident that banks must rethink the dynamics of collateral so as to increase the number of SME owners who can qualify for loans.

\section{Recommendations from the study}

From the findings of the study and ensuing discussions and conclusions, the following is a pertinent recommendation:

1. Banks should review collateral demands for SME owners to allow for more items of value to be used as security as this will encourage business people to borrow, hence improving the performance of SMEs in terms of capitalization, cash flow and profitability.

\section{RECOMMENDATIONS FOR FURTHER RESEARCH}

The scope and limitations of this study could not allow it to delve into the following related research topics, which other researchers are encouraged to pursue:

1. A replication of the current study in other geographical areas for comparison purposes.

2. Role of loan collateral on the performance of SMEs in a specific industry, for example agribusiness.

3. Other factors that constitute the unexplained $47.3 \%$ affecting SMEs performance apart from credit accessibility.

\section{REFERENCES}

[1] Abdi,A. (2015). The Regulatory and Supervision Framework of the Microfinance in Kenya. International Journal of Social Science Studies Vol.3 No.5 Sep 2015.

[2] Ackah,J. \&Vuvor, S. (2011). The Challenges Faced by Small \& Medium Enterprises (SMEs) in Obtaining Credit in Ghana. School of Management.

[3] Akerlof, G.A. 1970. The market for 'lemons': Quality Uncertainty and the Market Mechanism. Quarterly Journal of Economics 84, 488-500.

[4] Ayuba ,B. and Zubairu.M.(2015). Impact of Banking Sector Credit on the

Growth ofSmall and Medium Enterprises in Nigeria. Journal of Resources Development andManagement.

[5] Binks, M., Ennew.C\& Reed (1992).Information Asymetries and the Provision of Finance to Small Firms. International Small Business Journal

[6] Capital Market Authority (2015).Capital Raising Opportunities for SMEs: The Development of Micro-cap Securities in Kenya Conference on DevelopmentEconomics, World Bank, Washington

[7] Central Bank of Kenya (2016). Banking (Ammendment) Act. Kenya Gazette Supplement No.143 (Act no.25 of (2016).

[8] Central Bank of Kenya (2013). Bank supervision Annual report 2014. Nairobi: CBK

[9] Central Bank of Kenya (2017) Bank Supervision Annual Report 2018, Nairobi.CBK

[10] Central Bank of Kenya (2018) Impact of Interest Rate Capping on Kenyan Economy. Nairobi: CBK

[11] Ciano.D, Russo.P\&Vacca.V (2015). Financing SMEs in Europe: Stylized Facts,Policies and Challenges. Research Gate

[12] Deiana.R and Minsat.A (2017) Financing African SMEs. International Economic Forum

[13] Delloite (2016). Kenya Economic Review. Kenya economic outlook.

[14] ECB (2013).Cost of Borrowing Indicators: Methodological Note. DG Statistics. ECB Public. 2013.

[15] Etemesi,E,M (2017). Credit Access from Commercial Banks and Growth of Small and Micro Enterprises in NairobiCentral Business District: MBA Research Paper USIU.

[16] European Central Bank (2016). Survey on the Access to Finance of Enterprises in EuroArea. European Central Bank.

[17] Financial Sector Deepening Kenya (2015). Annual Report Retrieved from the Financial Sector Deepening Kenya Website:http://www.fsdkenya.org/annualreport 2015.

[18] Guantai.K and Mahesh,R(2018) The Impact Assessment of Micro Finance

[19] Inclusion and Business Growth:Study of Micro,Small and Medium Enterprises in IgembeSouth.American Journal of Finance

[20] Karanja, J. G., Mwangi, A. K., \&Nyakarimi, S. N. (2014). Analysis of Factor

[21] Influencing Access to Credit Services by Women Entrepreneurs in Kenya. Research Journal of Finance and Accounting.vol.5,No.pp 44-55.

[22] Katua, N.T. (2014). The Role of SMEs in Employment Creation and

[23] Economic Growth in Selected Countries. International Journal of Education and Research. Vol. 2: pp. 246-272. 
[24] KNSB (2015).Meru County statistical Abstract. KNSB Economic Survey (2015)

[25] KNBS, (2016) Kenya National Bureau of Statistics. KNSB Economic Survey (2016).

[26] Meru County (2017). Meru County Licensing Report. County Government of Meru.

[27] Muratha, V. (2015). Factor affecting Credit Accessibility among Young Entrepreneurs inKenya: A case study of Family Bank Limited. MBA Research Paper, USIU.

[28] Nguyen,T.,Gan,C. and Hu,M. (2015). Analysis of Credit Accessibility of Small and Medium Sized gEnterprises in Vietnam, Journal of Business perspective.

[29] Orodho, J. (2003). Introduction to Survey Research Design. Qualitative Approaches.Nairobi: Acts Press.

[30] Republic of Kenya .Micro and Small Enterprises Act of 2012.Kenya Gazette Supplement Act no.55 of 2012.

[31] Republic of Kenya Vision 2030, Deloitte Kenya economic outlook, 2016

[32] United Nations Industrial Development Organisation (2012). Empowering Women:Fostering Entrepreneurship. United Nations Industrial Development Organization Annual Report. Vienna, Austria.

[33] World Bank Enterprise Surveys (2010). Access to Credit Among Micro Small andMedium Enterprises. http:// www.enterprisesurveys.org. 